\title{
OCCUPATIONAL INFECTION BY THE HEPATITIS B VIRUS: RISK AND PREVENTION MEASURES
}

\author{
Bruno Francisco Real de Lima1, Maria Cristina Waffae ${ }^{2}$, Elizabeth Niglio de Figueiredo², \\ Rosangela Filipinni ${ }^{1}$, Maria Claudia de Brito Luz ${ }^{2,3}$, Ligia Ajaime Azzalis ${ }^{2,3}$, \\ Virginia Berlanga Campos Junqueira ${ }^{2,3}$, Fernando Luiz Affonso Fonseca ${ }^{2,3}$, \\ Loide Corina Chaves ${ }^{1}$
}

\begin{abstract}
Introduction: infection by the hepatitis B virus (HBV) is one of the most serious problems of public health because of the great number of people infected by this etiological agent. Objectives: to check the knowledge presented by the nursing staff on the mode of transmission of hepatitis $B$ virus (HBV) and the resulting damage to human health and to identify the knowledge of the nursing staff on prevention measures used to avoid occupational infection by this virus and, further, to investigate the immunization situation of the nursing staff against HBV. Methods: a quantitative study conducted in 2008. The sample consisted of 38 numbers of the nursing staff of a Teaching Public Hospital in ABC (São Paulo) a form being used to make the data collection. Results: sexual intercourse was reported by most $(24.57 \%)$ of the nursing staff as a mode of transmission of HBV. The use of personal protective equipment (PPE) was mentioned by $41.54 \%$ of these professionals as a way of avoiding HBV infection. Only $2.63 \%$ of participants reported not knowing if some colleague had already been the victim of an accident with drill cutting materials. All the participants in this study had previonsly been immunized against HBV. Conclusion: the professionals in this study are prepared for the use of standard precautions.
\end{abstract}

Key words: transmission of hepatitis B virus; universal precautions; nursing staff.

\section{INTRODUCTION}

Infection by the hepatitis B virus (HBV) is one of the most serious problems of public health because of the great number of people infected by this etiological agent. The World Health Organization (WHO) says that approximately 350 million people are chronic bcarre of this virus in several regions of the world; about two million of them in Brazil ${ }^{1}$.

The HBV can cause acute and chronic liver disease after an incubation period of from 45 to 180 days, when infected individuals develop acute hepatitis, frequently subclinical and anicteric.

Only $20 \%$ develop jaundice and about $0.2 \%$ of the patients die from it. Classically, it is accepted that acute HBV infection can be cured in from 90 to $95 \%$ of cases and that it is a chronic carrier in the remaining 5 to $10 \%$.

Half these patients show no liver disease, being called healthy carriers; but the other half present varijing intensity of inflammatory activity in the liver for many years and may develop liver cirrhosis and/or hepatocellular carcinoma in the later stages of the disease ${ }^{2}$.

The most common ways to transmit the HBV are: unprotected sex; performing dental and surgical interventions, hemodialysis, tattooing, ear piercingring without proper sterilization or use of disposable equipament; drug use with shared syringe, needles or other equipment; transfusion of contaminated blood and its derivatives; vertical transmission (mother/child); breastfeeding and occupational accidents ${ }^{1}$.

1 Curso de Enfermagem - Faculdade de Medicina do ABC (FMABC), Santo André, (SP) Brasil.

2 Escola Paulista de Enfermagem - Universidade Federal de São Paulo (UNIFESP), São Paulo, (SP) Brasil.

3 Curso de Gestão em Saúde Ambiental - Faculdade de Medicina do ABC (FMABC), Santo André, SP, Brasil. Corresponding author: profferfonseca@gmail.com

Suggested citation: Lima BFL, et al. Occupational infection by the hepatitis b virus: risk and prevention measures; Journal of Human Growth and Development 2013; 23(2): 184-189

Manuscript submitted Mar 01 2012, accepted for publication Apr 192013. 
The occupational HBV infection in health professionals is considered one of the most dangerous diseases because of the possible exposures (percutaneous or mucous) to the blood of people under their care, infected by this virus ${ }^{3}$.

Most occupational exposure to infected blood and body fluids occurs through accidental performation with needles ${ }^{4}$. There-use of needles is one of the causes of these exposures ${ }^{5,6}$.

The habit of resurfacing needles used on patients is still observed in the daily activities of health professionals 7,8 , in spite of the current guidelines for prevention and control of these occupational infections.

Surgical gloves made of latex, when not damaged, are an effective barrier to the penetration of microorganisms ${ }^{9}$.

It the situation of cleaning workers who have to remove hospital waste the waste disposal too and frequently hurt themselves with improperly discarded needles is also worrying ${ }^{1}$.

The risk of acquiring an infection after occupational exposure depends on the type and severity of the wound, its size, wether there is any blood with, as well as the patient's clinical conditions.

In percutaneous exposures involving blood actually contaminated $\mathrm{HBV}$ and with the presence of $E$ antigen of the hepatitis $B$ virus ( $\mathrm{HBeAg}$ ), a marker of viral replication, the risk of infection may be higher than $30 \%$, however, if the patient - cause of the accident - presents positive $\mathrm{S}$ antigen of the hepatitis $B$ virus ( $\mathrm{HBsAg}$ ) and antibodies against the $E$ antigen of the hepatitis $B$ virus (anti-HBe) positive (no viral replication), the risk is approximately $6 \%{ }^{9}$.

To prevent or eliminate the risk of occupational HBV infection, health professionals must observe the Standard Precautions (SP) that are supplemented by personal protective equipment (PPE gloves, masks, goggles, aprons) while they are giving direct assistance to the client.

The Standard Precautions (SP) are preventive measures needed mainly to protect the health professional during procedures that may entail the risk of potential contact with the body fluids of patients infected with the contagious etiologic agents, especially the HBV. These precautions should be used with all patients whatener their diagnosis, from their admission until discharge ${ }^{10}$.

Besides these preventive measures, these professionals may also be immunized, in public hospitals, with the vaccine against this virus. If SP are properly adopted and everybody is aware of the importance of immunization, the risk of occupational infection can be significantly reduced ${ }^{11}$.

Concerning the data presented, we believe that this study involves important questions in relation to health professionals whose activities are directly related to assisting patients with $\mathrm{HBV}$. It is also essential to pay attention to the importance of the vaccination of nursing staff against $\mathrm{HBV}$ and their agreement to this; obtain it is clear, there- fore, that those workers must have the necessary knowledge and skills to protect themselves and thus avoid the spread of this disease.

The objectives of this study were to check the knowledge presented by the nursing staff on the mode of transmission of the hepatitis $B$ virus and the resulting damage to human health; to identify the nursing staffs knowledge on the prevention measures used to avoid occupational infective by hepatitis $B$ virus, and to investigate the immunization situation of the nursing staff studied against HBV.

\section{METHODS}

This is a descriptive and quantitative study, whose data were obtained through field research.

The study was conducted from July 1 st to July 30th 2008 at a Teaching Public Hospital in the $A B C$ region (Santo André, São Bernardo e São Caetano Counties, São Paulo State), which has an attende a large area and is classified as a midrange hospital, after the approval of the Ethics of the in Research Committee on Humans ABC Medical school (protocol 182/2008), according to Resolution $196 / 96$ of the. Ministry of Health.

The sample population was composed of 38 members of the nursing staff, of which 21 (55.26\%) belonged to the category of professional nursing auxiliary, 10 were nursing technicians, 7 were nurses and $39.45 \%$ (15) of these had been allocated to the inpatient unit of the surgical clinic. Most (32, $84.19 \%$ ) of the population ware female.

Initially the research project were sent to the nursing manager and and a covering lether hospital clinical director requesting authorization to conduct this study.

After the nursing staff agreed to participate in this study and signited informed the consent form, the data were collected.

A form was used for data collection; it was composed of thirteen (13) open questions, structured and semi-structured. Open questions and semi-structured interviews were intended not only were greater spontaneity in the informants' responses but obtain also to achive the objectives proposed on this study.

The variables focused were: identification of the informant; professional knowledge on the mechanisms of HBV transmission and the problems that this can cause to human beings' health; the correct measures used to prevent occupational transmission of hepatitis $B$ and the approaches adopted by the institution to avoid occupational accidents; the availability of personal protective equipment provided by the institution and the occurrence of occupational accidents.

Data were analyzed by absolute and relative frequencies and presented in tables or in text form were the results ware numerically small. 


\section{RESULTS}

Table 1: Frequency of nurses, technicians and nursing assistants on the mode of transmission of hepatitis B. São Bernardo do Campo, 2008

$\begin{array}{lrr}\text { Method of transmission of hepatitis B virus } & \text { No } & \% \\ \text { Sexual Transmission } & 28 & 24.57 \\ \text { Direct contact with blood } & 23 & 20.17 \\ \text { Blood Transfusion } & 21 & 18.42 \\ \text { Accident drill Cutters } & 17 & 14.91 \\ \text { Contact Secretions } & 14 & 12.28 \\ \text { Breastmilk } & 6 & 5.26 \\ \text { Sharing syringes } & 2 & 1.75 \\ \text { Transplacental } & 1 & 0.88 \\ \text { Contact with Urine } & 1 & 0.88 \\ \text { Contact with Vaginal Discharge } & 1 & 0.88 \\ \text { Total } & 114 & 100.00\end{array}$

The nursing staff might answer this question in different ways; so the percentage was calculated from the total responses given.

Table 2: Frequency related to the knowledge of nurses, technicians and nursing assistants on preventive measures to prevent the transmission of hepatitis B. São Bernardo do Campo, 2008

$\begin{array}{lrr}\text { Prevention measures } & \text { No } & \% \\ \text { Use of PPE } & 27 & 41.54 \\ \text { Use of Gloves } & 11 & 16.92 \\ \text { Use of Protective Eyewear } & 6 & 9.23 \\ \text { Vaccination against HBV } & 5 & 7.69 \\ \text { Use of apron } & 4 & 6.15 \\ \text { Use of Mask } & 3 & 4.61 \\ \text { Lectures } & 2 & 3.08 \\ \text { Guidelines } & 2 & 3.08 \\ \text { Care drill Cutters } & 1 & 1.54 \\ \text { Condom } & 1 & 1.54 \\ \text { Laboratory Tests } & 1 & 1.54 \\ \text { Handwashing } & 1 & 1.54 \\ \text { Isolation of patients with HBV } & 1 & 1.54\end{array}$

The nursing staff might answer this question in different ways; so the percentage was calculated from the total responses given.

\section{DISCUSSION}

Most of the responses of the nursing staff reported that sexual transmission is implicated in the transmission of HBV 28 (24.57\%) cases being mentioned, while $20.17 \%$ (23) of the responses attributed the transmission of this virus to direct contact with blood (Table 1 ).

The nursing staff's knowledge level related to the mode of hepatitis $B$ virus transmission is consistent with the literature since the transmission of HBV occurs mainly through the parenteral and sexual routes, which were more frequently mentioned in these categories. The strict control exercised today in most blood banks has almost eliminated blood transmission of the virus in some geographical ar- eas. Nowadays, parenteral acquisition occurs, with few exceptions, only in injecting drug users, in accidental inoculations with minimal amounts of blood or, more rarely, by performing acupuncture and tattooing, which emphasizes the high risk of the use of sharps instruments, although these instruments are common in the nursing staff's professional practice.

Sexual transmission is caused by the presence of HBV in semen and vaginal secretions, which facilitates the passage of infective particles through mucosal surfaces during sexual intercourse. Thus hepatitis B can be considered one of the most important man's diseases sexually trans-mitted human diseases ${ }^{2}$.

As regard preventive measures to prevent hepatitis B transmission, $41.54 \%$ of the responses 
of the nursing staff noted that the use of personal protective equipment can avoid repareded hepatitis B transmission. Since $7.69 \%$ (5) regarded vaccination as a preventive measure and $3.08 \%$ (2) observed that the lecture offered by the institution were a means of information programs (Table 2).

Some preventive measures are very important in reducing the risk of HBV transmission during patient care. Thus, in 1996, the CDC (Centers for Disease Control and Prevention, USA) edited the Guideline for Isolation and Precaution with recommendations to be adopted in the care of any patient, whatwer their diagnosis, called Standard Precautions (SP). These measures include hand hygiene, use of personal protective equipment (PPE), vaccination against hepatitis $B$ and proper disposal of sharp ${ }^{12,13}$. Thus, we highlight the importance the knowledge and awareness of professional nursing staff in relation to the adoption of preventive measures against HBV, since they are constantly at risk by their direct or indirect assistance to patients.

According to $100 \%$ of the population studied, the research institution provides adequate PPE to their employees and all participants of this study had been immunized against HBV.

The implementation of the SP measures in the daily activities of direct patient care ensures protection to healthcare professionals against infections transmitted by blood or body fluids, or not the source of infection is known. These measures constitute the first strategy for successful hospital infection control ${ }^{13}$. It is essential that hospital managers require accuracy in the use of SP, ensure that the professionals adapt the recommended standards and discussion the effects of negligence if these rules are not obeyed; so that all these professionals will accept SP${ }^{14}$.

By identifying the occurrence of occupational accidents by the member of the nursing staff, 26 of the respondents $(68.42 \%)$, the majority of them, answered that they had never been victims of an accident involving sharp instruments, whereas 12 $(31.58 \%)$ answered affirmatively.

When they were asked if they were aware of the occurrence of occupational accidents with sharp instruments among coworkers, only $2.63 \%$ of the members of the nursing staff answered that no colleague had an accident involving sharp instruments; although $97.37 \%$ (37) of the nursing staff reported that one or some of their colleagues had occupational accidents with this type of material.

Because of accidents with sharps, nursing professionals suffer from a greater occupational exposure to bloodborne pathogens 7,15 , probably because they assume activities wathed to the patient.

Notification of accidental cases at work is compulsory and essential so that the computerization of these data way provide reliable data for the evaluation and control of this type of accident. In Brazil, training nor personal development calling for vigilance in the case of occupational accidents ${ }^{8}$ is good enough, and in many cases these accidents are not reported due to lack of manpower and $\mathrm{CCIH}$, on of a Specialized Safety and Medicine Service (SESMT). In a study of 500 professionals of a public hospital in São Paulo on the occurrence of occupational accidents, most the people who suffered this type of accident did not report it ${ }^{16}$.

Therefore, one should highlight the need for continuing educational programs on the importance of SP implementation in order to prevent occupational risks of infection, to prepare health professionals to perform their daily care activities more safely, as well as about the importance of occupational accident notification ${ }^{17}$.

Most occupational accidents occur during the administration of medication. From December 1999 to August 2002, in São Paulo, 3513 occupational accidents were reported with exposure to biological fluids. The following characteristics are present in 1715 records relating the circumstances and the occurrence of the accident: 277 exposures (16.2\%) occurred during the administration of medication, $275(16.0 \%)$ because improper disposal of the material, $230(13.4 \%)$ during vascular punctures, 176 $(10.3 \%)$ in surgical procedures, $122(7.1 \%)$ in dental procedures, and $80(4.7 \%)$ because of the recapping of needles ${ }^{8}$.

The possibility of HBV transmission through occupational accidents, needlek or sharp injuries can reach $40 \%$ in exhibits when the source patient has reactive $\mathrm{HBsAg}$ serology ${ }^{18}$. According to the literature, the percentage of HBV seraconversion is considerable after occupational exposure, consequently it is very important to adopt preventive measures during direct patient care activities, with a view to avoiding this type of occupational infection.

Although in this study the number of people who were victims of occupational needle accidents, $12(31.58 \%)$, is lower than those who were not, 26 $(68.42 \%)$, this situation demands more attention since it implies the potential risk of these professionals being victims of occupational infection.

According to the guidelines used by the research institution to face the question of occupational accidents, $22(24.72 \%)$ of the nursing team responses mentioned collecting patient and employee examinations, while $19.10 \%$ (17) reported the routing to infectious and $17.98 \%$ (16) observed filling out the form for reporting accidents at work. Notifying the occupational physician was related in $8(8.99 \%)$ responses of the nursing team, taking necessary medications was reported in 8 ( $8.99 \%)$ and the remaining responses mentioned accident reporting to the nursing sector, vaccine control, periodic conducting, etc.

The professionals who suffer any accident with biological material which is supposed to be contaminated should receive emergency medical treatment, because the prevention of HIV and HBV should be initiated as soon as possible ${ }^{18}$. The health institution, the hospital or the laboratory is responsible for 
this procedure, and this kind of treatment must be a routine whenever these accidents happen ${ }^{6}$.

In relation to health professionals being infected by hepatitis B at the institution, 100\% (38) of the nursing staff said they do not know of any case in the institution where they work.

The transmission HBV and other bloodborne pathogens through occupational infections, particularly with cutting material, are other important ways to be infected by this virus. The nursing staff are the most likely victims of this kind of accident ${ }^{4}$. Occupational HBV infection is rare when preventive measures are properly adopted by health professionals ${ }^{19}$. Therefore, standard precautions should be implemented in direct patient care from admission to discharge.

Most of the nursing team, $13(18.06 \%)$ times, mentioned liver cirrhosis as a kind of injury caused by HBV infection. This disease has an incidence rate from 2 to $6 \%$ of patients with HBeAg positive chronic hepatitis and $8-10 \%$ in patients with $\mathrm{HBeAg}$ negative chronic hepatitis. Several factors may influence the prognosis and progression of chronic hepatitis $B$ to cirrhosis, such as older age; generally, this may occur with individuals over 35 years, $\mathrm{HBeAg}$ positivity, high viral load and chronic use of alcohol. Among HIV-infected patients, HBV infection increases not only the risk of liver cirrhosis but also death from liver failure, especially when serum CD lymphocytes are low ${ }^{20}$.

Human health problems harm the life of those infected with HBV, because these people suffer from weakness, anorexia and malaise during the illness's prodromal period. At this stage carriers may refer to diffuse abdominal pain, nausea, intolerance to different food, taste disturbance, vomiting and abdominal discomfort. There are also many references to arthritis, arthralgias and myalgias, as well as the observation of skin rashes similar to hives or rubelliform. Physical examination may reveal painful hepatomegaly ${ }^{1}$.

The transmission risks and the health problems of the HBV carriers show that the whole nurs-

\section{REFERENCES}

1. Focaccia R, Veronesi R. Tratado de Infectologia. 3a Ed. São Paulo: Atheneu, 2005. p.2388.

2. Ferreira MS. Diagnóstico e Tratamento da Hepatite B. Rev Soc Bras Med Tropical. Uberaba: 2000; 33(4): 389-400.

3. Soriano EP, Carvalho MVD, Carneiro GR, Guimarães LL, Santos FB. Hepatite B: avalização de atitudes profiláticas frente ao risco de contaminação ocupacional. Rev Odontologia Clínico Científica. Recife: 2008; 7 (3): 227-234.

4. Marziale MHP, Nishimura KYN, Ferreira MM. Riscos de contaminação ocasionados por acidentes de trabalho com material perfuro- ing team need considerate knowledge of this subject, because they participate in dangerous activities, exposing themselves to accidental contact with substances and sharp equipment, which may cause the virus infection. Future research on this subject may significantly help to reduce accidents and occupational transmission of HBV to these professionals, as well as contributing to everybody's continuous education and awareness.

\section{CONCLUSIONS}

According to the results obtained in this study and its proposed objectives, we may conclude the participants in this study have a level of knowledge of hepatitis $B$ virus transmission that can be considered consistent with the literature, because many of them reported that one may get the virus by sexual transmission and direct contact with blood. Almost all the nursing staff has enough knowledge of preventive measures against HBV, since $41.54 \%$ of the participants mentioned the use of personal protective equipment (PPE) and $16.92 \%$ indicated the use of gloves, the latter being considered one of the most important pieces of personal protective equipment.

On the other hand, the occupational accidents with sharp material are very worrying, since $31.58 \%$ (12) of the participants in this study reported they had already been victims of it. Although the number of those who had been injured by sharp instruments is smaller, the potential risk of these professionals in acquiring infections with HBV and other bloodborne pathogens should be considered.

Finally, the results of this study showed that the nursing staff of the hospital concerned are prepared for the application of standard precautions; we must emphasize, however, the need for ongoing educational activities that sensitize healthcare professionals as to the appropriate use of these precautions, because these are the most effective way to prevent and reduce occupational accidents and infections.

cortante entre trabalhadores de enfermagem. Rev Latino-Americana de Enfemagem. São Paulo: $2004 ; 12(1)$ : 36-42.

5. Caixeta RB, Barbosa-Branco A. Acidente de trabalho, com material biológico, em profissinais de saúde de hospitais públicos do Distrito Federal, Brasil, 2002/2003. Cad Saúde Pública. Rio de Janeiro: 2005; 21(3): 737-746.

6. Simão SAF, Souza V, Borges RAA, Soares CRG, Cortez EA. Fatores associados aos acidentes biológicos entre profissionais de enfermagem. Cogitare Enfermagem. Rio de Janeiro: 2010; 15(1): 89-91.

7. Canini SRMS, Gir E, Hayashida M, Machado AA. Acidentes perfurocortantes entre trabalhadores de enfermagem de um hospital universitário 
do interior paulista. Rev. Latino-americana Enf. 2002; 10(2):172-8.

8. São Paulo. Vigilância de Acidentes com Material Biológico. SINABIO. CRT/DST/AIDS/CVE. Bol Epidemiol. 2002; Ano I (1).

9. Medeiros MT. Prevalência e fatores associados às hepatites virais em pacientes de hemodiálise. Rev Saúde Pública. 2004; 38: 187-93.

10. Robazzi MLCC, Marziale MHP. Alguns problemas ocupacionais decorrentes do trabalho de enfermagem no Brasil. Rev Bras Enfermagem. Brasília: 2000; 52(3):331-338.

11. Azevedo N, Gardelha C. Inovação em vacinas no Brasil: experiência recente e constrangimentos estruturais. História ciências e saúde. Manguinhos: 2003; 10( supl.2).

12. Lopes ACS, Oliveira AC, Silva JT, Paiva MHRS. Adesão às precauções padrão pela equipe do atendimento pré-hospitalar móvel de Belo Horizonte, Minas Gerais, Brasil. Cad Saúde Pública. Rio de Janeiro: 2008; 24(6): 1387-1396.

13. Pinheiro J, Zeitoune RCG. Hepatite B: Conhecimento e medidas de biossegurança e a saúde do trabalhador de enfermagem. Esc Anna Nery Rev Enfermagem. Rio de Janeiro: 2008, 12(2): 258-264.

14. Brevidelli MM, Cianciarullo TI. Fatores psicossociais e organizacionais na adesão às precauções-padrão. Rev Saúde Pública. São Paulo: 2009; 43(6): 907-916.

15. Sarquis LMM, Felli VEA. Acidentes de trabalho com instrumentos perfurocortantes entre os trabalhadores de enfermagem. Rev Esc Enferm USP. $2002 ; 36(3)$ : 222-30.

16. Cocolo AC. Equipes médicas e de enfermagem menosprezam riscos de acidentes. J Paulista. 2002; Ano 15: (174).

17. Chaves LC. Adesão às Precauções Padrão e Manipulação dos Resíduos Perfurocortantes de Serviços de Saúde pela Equipe de Enfermagem: conhecimento e conscientização. Tese (Mestrado em Ciências) - Secretaria de Estado da Saúde, São Paulo: 2003.

18. Martins Rj, Garbin CAS, Garbin AJI, Prieto AKC. Conhecimento e atitudes de profissionais da saúde frete à exposição ocupacional a material biológico. Revista Ciencia \& Trabajo. Chile: 2011; Ano 13 (113-115).

19. Rossato EM. Cobertura vacinal contra hepatite $B$ em profissionais de saúde de um município de médio porte da região noroeste do Rio Grande do Sul. Tese (Mestrado em Epidemiologia) - Universidade Federal do Rio Grande do Sul, Porto Alegre: 2009.

20. Fonseca JCF. História Natural da hepatite crônica B. Rev Soc Bras Med Tropical. 2007; 40(6): 672-677. 